\title{
Effects of low radiation and low temperature at meiosis on pollen viability and grain set in wheat
}

\author{
S Demotes-Mainard ${ }^{1 *}$, G Doussinault ${ }^{1}$, JM Meynard ${ }^{2}$ \\ 1 INRA, station d'amélioration des plantes, BP 29, F-35650 Le Rheu; \\ 2 INRA, laboratoire d'agronomie, F-78850 Thiverval-Grignon, France
}

(Received 22 February 1995; accepted 28 July 1995)

\begin{abstract}
Summary - Wheat plants at meiosis were subjected in a growth chamber to treatments combining 2 levels of temperatures $\left(15 / 18^{\circ} \mathrm{C}\right.$ and $1.5 / 8^{\circ} \mathrm{C}$ night/day) and 2 levels of radiation $\left(203 \pm 26\right.$ and $11 \pm 1 \mu \mathrm{mol} \mathrm{m} \mathrm{m}^{-2} \mathrm{~s}^{-1}$ photosynthetic photon flux density). Pollen viability at anthesis (fluorochromatic reaction) decreased in response to low radiation, but was not affected by chilling. There was no interaction between radiation and temperature. Varieties Moulin and Pernel had qualitatively the same response, but Moulin was more sensitive. These results were validated in 2 field experiments on Pernel. In the first, plants were exposed to $-2^{\circ} \mathrm{C}$ for $1 \mathrm{~h}$ on 3 consecutive days at different stages around meiosis. Cooling slightly reduced grain set, but there was no difference in the sensitivity of the developmental stages. In the second field experiment, plants were shaded at meiosis to receive $30 \%$ of the solar radiation. Shading strongly reduced kernel number per ear and induced sterility.
\end{abstract}

radiation / temperature / male sterility / meiosis / Triticum aestivum $\mathrm{L}=$ wheat

Résumé - Effets d'éclairements faibles et de températures basses au moment de la méiose sur la viabilité du pollen et la nouaison du blé. Des plantes de blé cultivées dans des enceintes climatisées ont été soumises, au stade méiose, à des traitements combinant 2 niveaux de températures $\left(15 / 18^{\circ} \mathrm{C}\right.$ et $1,5 / 8^{\circ} \mathrm{C}$ nuitjour) et de 2 niveaux d'éclairement (densité de flux de photons de $203 \pm 26$ et $11 \pm 1 \mu \mathrm{mol} \mathrm{m} \mathrm{m}^{-2} \mathrm{~s}^{-1}$ ). Le taux de pollen viable à l'anthèse (réaction fluorochromatique) a été réduit par le rayonnement faible mais n'a pas été affecté par les températures basses. II n'y a pas eu d'interaction entre le rayonnement et la température. Les variétés Moulin et Pernel ont présenté une réponse qualitativement identique, mais avec une sensibilité plus forte pour Moulin. Ces résultats ont été validés dans 2 essais au champ avec la variété Pernel. Dans le premier, les plantes ont été exposées à $-2^{\circ} \mathrm{C}$ pendant $1 \mathrm{~h} 3 \mathrm{j}$ consécutifs, à différents stades encadrant la méiose. Le froid a légèrement réduit le nombre de grains par épi mais son effet n'a pas varié avec le stade de développement auquel il était appliqué. Dans le second essai, des parcelles ont été ombrées, à la méiose, avec un filet ne laissant pénétrer que $30 \%$ du rayonnement incident. L'ombrage a fortement réduit le nombre de grains par épi et a induit une stérilité.

éclairement / température / stérilité mâle / méiose /Triticum aestivum $L=b l e ́$

* Correspondence and reprints: INRA, laboratoire d'agronomie, F-78850 Thiverval-Grignon, France. 


\section{INTRODUCTION}

Low grain set has been reported on several occasions in various varieties of winter wheat grown in the field (Ledent et al, 1988; Leterme et al, 1994). This phenomenon always involved many fields within a region, suggesting the influence of the climatic conditions. An analysis indicated that this poor grain set was associated with low, but positive temperatures occurring near the meiotic stage (Meynard and Sebillotte, 1994). However, the effect of the temperature could not always be dissociated from that of other parameters, notably solar radiation. It has been established that a reduction of both temperature and radiation at meiosis reduces grain set by inducing male sterility; female fertility is not affected, as shown by cross-pollination of treated and control spikes (Demotes-Mainard, 1994). However, the relative contributions of temperature and radiation remain unknown.

Chilling temperature at meiosis can induce pollen sterility and thus reduce grain set in several thermophilic crops, including sorghum (Downes and Marshall, 1971), coffee (Lanaud, 1983) and rice (Satake, 1991). The evidence for such an effect in temperate crops is much less extensive. Nevertheless, Zhu (1989) reported that low temperatures plus low humidity during stamen and pistil differentiation caused a high percentage of empty glumes in barley, but he did not study male and female development. In wheat, low grain set was recorded in field trials when the temperature at or around meiosis was low (Couvreur and Masse, 1985; Meynard and Sebillotte, 1994). Doussinault et al (1988) found a correlation between the percentage of abnormal pollen and seed set in plants chilled close to meiosis. In these experiments on wheat, the plants were grown under natural conditions, so that it was difficult to dissociate the effect of temperature from those of other climatic parameters.

$A$ reduction in the incident radiation during the month preceding anthesis decreases kernel number per ear in wheat (Evans, 1978; Fischer, 1985). The period of greatest susceptibility appears to be between 17 and $5 \mathrm{~d}$ before anthesis (Fischer and Stockman, 1980). Male development, which is altered by several types of climatic stresses at meiosis (Saini and Aspinall, 1981; Saini et al, 1984), was not studied in these experiments. The poor grain set and the observation that darkness at meiosis can cause pollen sterility in sorghum (Alami et al, 1988) suggest that low radiation at meiosis can depress kernel number in wheat by inducing pollen sterility. We therefore investigated the effects of low radiation and low temperature at meiosis on pollen viability and its consequences for grain set in wheat.

\section{MATERIALS AND METHODS}

A first experiment was conducted in a growth chamber, so as to dissociate the effects of temperature and radiation and to study their consequences on pollen fertility. These results were then validated in field conditions in 2 experiments.

\section{Chamber experiment: effects of low radiation and low temperature}

Two varieties of winter wheat (Triticum aestivum $L$ ), Moulin and Pernel, were used. Pre-germinated seeds were sown on 15 December 1992 in pots filled with soil, at one seed per pot and vernalized outdoors near Rennes (France, $48^{\circ} 6^{\prime} \mathrm{N}, 1^{\circ} 5^{\prime} \mathrm{W}, 40 \mathrm{~m}$ elevation). Only the main shoot and the first 3 primary tillers were kept on each plant by cutting the tillers once a week during tillering.

Meiosis is synchronous in the microsporocytes and the megasporocyte within a floret (Bennett et al, 1973). Floral development was therefore assessed on the male part alone. The relationship between phenology and male gametophyte development was first established on a sample of plants (destructive method). This was then used for the non-destructive determination of the meiotic stage in the main shoot of each plant. The stage of microsporocyte development was determined under a light microscope by the squash technique, using acetocarmine to stain the nuclear chromatin. When the oldest florets in the ear of the main shoot reached the first meiotic division, we measured the distance between the ligule of the penultimate leaf and the tip of the ear felt through the leaf sheaths, using a sample of 5 plants for each variety and culture conditions. This distance is constant for one variety under a given growth condition between the pre-meiotic stage and the microspore stage (Demotes-Mainard, 1994). This relationship between phenology and male gametophyte development was then used to select plants whose oldest florets in the main shoot ear were in the first meiotic division. This stage will hereafter be referred to as 'meiosis'.

At meiosis, the plants were transferred to different growth chambers and subjected to 1 of 4 combinations of temperature and radiation for $7 \mathrm{~d}$ :

TR: $15 / 18^{\circ} \mathrm{C}$ night/day, $203 \mu \mathrm{mol} \mathrm{m} \mathrm{m}^{-2} \mathrm{~s}^{-1}$ photosynthetic photon flux density (PPFD)

Tr: $15 / 18^{\circ} \mathrm{C}$ night/day, $11 \mu \mathrm{mol} \mathrm{m} \mathrm{m}^{-2} \mathrm{~s}^{-1}$ PPFD

tR: $1.5 / 8^{\circ} \mathrm{C}$ night/day, $203 \mu \mathrm{mol} \mathrm{m} \mathrm{m}^{-2} \mathrm{~s}^{-1} \mathrm{PPFD}$ tr: $1.5 / 8^{\circ} \mathrm{C}$ night/day, $11 \mu \mathrm{mol} \mathrm{m} \mathrm{m}^{-2} \mathrm{~s}^{-1}$ PPFD 
The photoperiod was $16 \mathrm{~h}$ in all cases. Radiation was provided by fluorescent lamps (low level) and high pressure sodium lamps (control level).

The plants were cultivated in 2 growth conditions between the end of vernalization and the beginning of the experimental treatments because of material constraints. A first group was grown in a growth chamber (203 $\mu \mathrm{mol} \mathrm{m} \mathrm{m}^{-2} \mathrm{~s}^{-1}$ PPFD or $11.7 \mathrm{~mol} \mathrm{~m}^{-2} \mathrm{~d}^{-1}$, $15 / 18^{\circ} \mathrm{C}, 16 \mathrm{~h}$ photoperiod). These plants were subjected to treatments $T R, T r$ and tr at meiosis. A second group of plants remained outdoors until meiosis. The minimum photosynthetically active radiation was 9.5 $\mathrm{mol} \mathrm{m} \mathrm{m}^{-2} \mathrm{~d}^{-1}$ during the fortnight preceding meiosis and the minimum air temperature was $6.5^{\circ} \mathrm{C}$. These plants underwent treatments TR and tR.

After the $7 \mathrm{~d}$ treatment, all the plants were transferred to the same growth chamber $\left(15 / 18^{\circ} \mathrm{C}\right.$ night/day, $109 \mu \mathrm{mol} \mathrm{m}-2 \mathrm{~s}^{-1}$ PPFD) where they remained until flowering. Pollen viability was evaluated just before anther dehiscence using the fluorochromatic reaction (FCR) test (Heslop-Harrison and Heslop-Harrison, 1970). Thirty-six anthers were examined for each treatment except the TR-grown outdoors, for which 18 anthers were examined. The percentage of viability was assessed from a sample of 400 pollen grains per anther. The anthers were collected in the first and second florets of the spikelets in the middle region of the ears of the main shoots and first tillers. Anthers treated at similar developmental stages were thus examined.

The results were analysed by analyses of variance. The experimental design was incomplete, and so it was not possible to test the interactions between the culture conditions before meiosis and the climatic parameters at meiosis (temperature and radiation). However, it is reasonable to assume that these interactions were not significant, because we previously observed no interaction between growth conditions prior to meiosis and chilling plus low radiation at meiosis (Demotes-Mainard and Doussinault, 1993).

\section{Field experiment 1: effects of low temperature}

This experiment aimed to investigate (a) whether the results obtained in the chamber experiment were rele- vant to field situations and (b) whether they were stable when low temperatures occurred at different stages surrounding meiosis. Therefore, grain set was measured in field-grown plants cooled at several stages between emergence of the flag leaf and heading.

The winter wheat variety Pernel was sown near Rennes on 16 October 1991 on a loamy soil. The sowing density was 280 seeds $\mathrm{m}^{-2}$. Weeds, diseases and insects were controlled.

The plants were cooled at various stages using a transportable cold room that could contain about 50 adjacent ears in a sowing line. At each development stage, temperatures of -1 to $-2^{\circ} \mathrm{C}\left( \pm 1^{\circ} \mathrm{C}\right)$ were applied for $1 \mathrm{~h}$ for 3 consecutive days. To simulate a minimum night temperature, a first sample was cooled at dawn and a second sample $1 \mathrm{~h}$ later. Two samples located near each cooled one were used as controls. The cooling treatments were applied at the emergence of the flag leaf, $3 \mathrm{~d}$ ( 25 degree-d) before meiosis, at the beginning of meiosis and at heading. Table I shows the ambient temperature during the $3 \mathrm{~d}$ cooling treatments. The meiotic stage was assessed by cytological observations of microsporocyte development.

Out-crossings were likely in cases of pollen sterility, or asynchronous male and female development, because the treated plants were surrounded by untreated ones. To prevent out-crossings, all the ears studied were covered with cellophane bags before flowering. The total number of grains per ear was counted at maturity. The fertility of the lateral florets, defined as the percentage of first and second florets of each non-aborted spikelet that developed a grain, was also measured to allow comparison with the growth chamber experiment.

\section{Field experiment 2: effects of low radiation}

Four plots of winter wheat variety Pernel were sown on 6 November 1990 near Rennes on a loamy soil. The sowing density was 300 seeds $\mathrm{m}^{-2}$. Weeds, diseases and insects were controlled.

Table I. Ambient temperature during the $3 \mathrm{~d}$ of application of the cooling treatment. Field experiment 1.

Developmental stage of the plants
Minimum air temperature $\left({ }^{\circ} \mathrm{C}\right)$ during the $3 d$

\section{Means over the $3 d$}

$\begin{array}{ccc}\text { Minimum air } & \text { Mean air } & \text { Maximum air } \\ \text { temperature }\left({ }^{\circ} \mathrm{C}\right) & \text { temperature }\left({ }^{\circ} \mathrm{C}\right) & \text { temperature }\left({ }^{\circ} \mathrm{C}\right)\end{array}$

Emergence of the flag leaf 25 degree- $d$ before meiosis Meiosis Heading 
Two of these plots were chosen at random and were shaded so that only $30 \%$ of the photosynthetically active sunlight reached the plants. The plants were shaded for 184 degree-d from 15 May 1991, when meiosis started in the oldest ears, to 27 May 1991, when meiosis was finished in all the ears. Meiosis was assessed by cytological observations of development of the pollen mother cells. The climatic conditions during shading are shown in table II. The red/far red ratio was 0.90 in the shade while it was 1.15 in the incident radiation. Thus, the amplitude of variation of the red/far red ratio due to the shade was similar to that observed in natural daylight (Varlet-Grancher et al, 1993).

The number of kernels per ear was determined at maturity for 3 samples per plot, each of $0.5 \mathrm{~m}$ in 2 adjacent sowing rows. The chaff and straw dry matter (the straw dry matter is all above-ground dry matter except the grain) were measured on the same samples. Two characteristics of male development, which are easy to observe in field grown crops, were examined: the rate of natural hybrids in the progeny and pollen dissemination. As a general rule, wheat is 96-100\% autogamous. Out-crossing therefore occurs either when the plant has reduced male fertility and is female fertile, or when male and female developments are asynchronous. Kernels were harvested from each shaded and control plot at maturity and sown the next year. The percentage of these plants with a phenotype different from that of Pernel (hybrid plants) was determined at heading on a total of 700 plants. The rate of hybrids in the progeny was an underestimation of the rate of out-crossing, since outcrossings by pollen of other plants of the variety Pernel could not be detected. Pollen dissemination was studied on anthers collected at anthesis, stained with acetocarmine and examined under a stereomicroscope. The pollen grains remaining in an anther after dehiscence tend to be packed at the base of the anther loculi. Absent pollen was therefore estimated by the percentage of the volume of the anther bags that was empty of pollen grains. Anther dehiscence and the percentage of pollen absent from the anthers (disseminated pollen) were recorded. Sixty-five anthers from one control plot and one shaded plot were examined.

\section{RESULTS}

\section{Chamber experiment: effects of low radiation and low temperature}

Pollen viability was assessed at anthesis by the fluorochromatic reaction. Three types of pollen grains were found: 1) fluorescent pollen grains without a vacuole, which is the normal type at anthesis $(\mathrm{FCR}+) ; 2)$ fluorescent pollen grains with one big, or in some cases several small vacuoles (FCR \pm ), for which non-resorption of the vacuole shows abnormal pollen maturation; and 3) non-fluorescent pollen grains (FCR-). The membrane integrity or the esterase activity of these pollen grains was altered.

Low radiation at meiosis reduced the proportion of normal type (FCR+) Moulin and Pernel pollen grains per anther, whereas the temperature had no effect (table III). The culture conditions before meiosis (growth chamber or outdoors) had no effect and there was no interaction between the temperature and the radiation. The effect of low radiation on pollen viability depended on the genotype. The amount of altered pollen grains in plants subjected to low radiation at meiosis was higher in Moulin than in Pernel (table IV). Low radiation also increased the proportion of type FCR \pm pollen grains more than that of FCR- in Moulin, whereas it had the opposite effect in Pernel.

\section{Field experiment 1: effects of low temperature}

This trial investigated whether sensitivity to low temperatures depended on the developmental stage at which cooling occurred (emergence of

Table II. Temperature and radiation during the shading period. Field experiment 2.

Control plots
Shaded plots 
the flag leaf, $3 \mathrm{~d}$ ( 25 degree-d) before meiosis, at the beginning of meiosis and at heading). The differences in kernel number per ear and fertility of the lateral florets between control and cooled plants were examined. Each control sample was paired with the adjacent cooled sample. The response of the crop to the treatment did not depend on the developmental stage, or on the time of cooling (dawn or $1 \mathrm{~h}$ thereafter) (table V).

The effect of the treatment on ear fertility was studied without differentiating between samples

Table III. Analysis of variance: effect on the proportion of viable pollen grains $(\mathrm{FCR}+)$, radiation and temperature at meiosis, culture conditions before meiosis and interaction between temperature and radiation. Chamber experiment.

\begin{tabular}{|c|c|c|c|c|c|c|}
\hline \multirow[t]{3}{*}{ Source } & \multicolumn{3}{|c|}{ Cv Moulin } & \multicolumn{3}{|c|}{ Cv Pernel } \\
\hline & $\cdots$ & 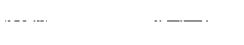 & $\cdots \cdots-$ & & & \\
\hline & $d f$ & Mean square & $\operatorname{Pr}>F$ & df & Mean square & $\operatorname{Pr}>F$ \\
\hline 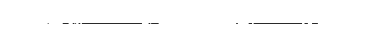 & $\cdots-$ & $-\cdots$ & & & & \\
\hline \multicolumn{7}{|l|}{ Factor } \\
\hline Radiation & 1 & 10.22 & 0.0001 & 1 & $2.99 \times 10^{-1}$ & 0.0001 \\
\hline Temperature & 1 & $4.88 \times 10^{-4}$ & 0.79 & 1 & $1.41 \times 10^{-2}$ & 0.091 \\
\hline Culture conditions & 1 & $1.66 \times 10^{-2}$ & 0.12 & 1 & $2.49 \times 10^{-3}$ & 0.48 \\
\hline Radiation $\mathrm{x}$ temperature & 1 & $2.14 \times 10^{-3}$ & 0.57 & 1 & $4.67 \times 10^{-3}$ & 0.33 \\
\hline Error & 154 & $6.64 \times 10^{-3}$ & & 160 & $4.89 \times 10^{-3}$ & \\
\hline
\end{tabular}

Table IV. Effect of the experimental treatments on the pollen viability assessed by the FCR test. Chamber experiment.

\begin{tabular}{|c|c|c|c|c|c|}
\hline \multirow[t]{2}{*}{ Variety } & \multirow{2}{*}{$\begin{array}{c}\text { Combination of } \\
\text { temperature and radiation }\end{array}$} & \multirow{2}{*}{$\begin{array}{c}\text { Conditions of } \\
\text { culture }\end{array}$} & \multicolumn{3}{|c|}{ Frequency per anther (\%) } \\
\hline & & & Pollen FCR+ & Pollen FCR \pm & Pollen FC \\
\hline Moulin & TR & Growth chamber & 90.0 & 5.2 & 4.8 \\
\hline & TR & Outdoors & 93.7 & 4.6 & 1.7 \\
\hline & $t R$ & Outdoors & 92.4 & 5.4 & 2.2 \\
\hline & $\operatorname{Tr}$ & Growth chamber & 8.8 & 83.3 & 7.9 \\
\hline & $\operatorname{tr}$ & Growth chamber & 9.3 & 83.1 & 7.7 \\
\hline Pernel & TR & Growth chamber & 92.6 & 2.9 & 4.5 \\
\hline & TR & Outdoors & 94.0 & 1.8 & 4.1 \\
\hline & $\mathrm{tR}$ & Outdoors & 90.4 & 1.8 & 7.8 \\
\hline & $\operatorname{Tr}$ & Growth chamber & 78.2 & 8.0 & 13.9 \\
\hline & $\operatorname{tr}$ & Growth chamber & 77.2 & 5.9 & 16.9 \\
\hline
\end{tabular}

Table V. Analysis of variance: effect of the stage of development and time of cooling on the difference in kernel number and fertility of the lateral florets between the control and the cooled samples. Field experiment 1.

Source Difference in kernel number per ear

df Mean square $\quad \operatorname{Pr}>F$

Factor

Stage

Time

3

3

14.10

3.38

0.102

2.66

0.341
Difference in fertility of the lateral florets

df Mean square $\quad \operatorname{Pr}>F$

18.84

0.543

0.61

0.878 
treated at different developmental stages and times. Cooling reduced both the kernel number per ear and the fertility of the lateral florets (Student's paired $t$-test, $P<0.05$ ), but this reduction was small (table $\mathrm{VI}$ ).

\section{Field experiment 2: effects of low radiation}

Shading at meiosis reduced the number of kernels per ear, but did not affect the chaff and straw dry weight at maturity (table VII). The pollen release per floret was estimated from the mean value for pollen lacking in the 3 stamens of each floret. Pollen dissemination was significantly reduced by shading at meiosis, due to poor pollen dispersal from the dehiscent anthers, whereas anther dehiscence was not affected. The occurrence of hybrids in the progeny was higher in shaded plots than in control ones.

\section{DISCUSSION}

\section{Effects of low temperature}

We investigated the effects of temperatures which may occur in fields in northern France at the period of meiosis. In the growth chamber experiment, chilling was applied for a longer period than the climatic sequences which are likely in natural conditions. A long period was used in order to chill the plants at different stages between pre-meiosis and microspore. The cool temperature was applied at different stages in the field experiment. Each condition involved 3 consecutive nights of treatment, as previous observations showed that reductions in grain set were observed when $3 \mathrm{~d}$ of chilling occurred (Meynard and Sebillotte, 1994).

Low temperature had no effect on the rate of viable pollen as assessed by the FCR test. Since

Table VI. Student's $t$-test by pair on the difference between control and cooled samples in grain set, independently of the developmental stage and time at which plants were subjected to cooling. Field experiment 1.

$\begin{array}{lccccc} & \text { Mean values } & \begin{array}{c}\text { Mean of the difference between } \\ \text { control and cooled samples }\end{array} & t_{\text {calculated }} & t_{5 \% \text { Student }} \\ & \text { Control Cooling } & \text { Con } & & 2.8 & 1.90 \\ \text { Kernel number per ear } & 34.7 & 31.9 & 3.9 & 2.66 & 1.90\end{array}$

Table VII. Effect of crop shading at meiosis on kernel number, dry weight and pollen dissemination. Field experiment 2.

\begin{tabular}{|c|c|c|c|c|c|c|c|}
\hline \multirow[t]{2}{*}{ Treatment } & \multirow[t]{2}{*}{ Kernels/ear } & \multirow{2}{*}{$\begin{array}{c}\text { Chaff dry weight } \\
\text { (g/ear) }\end{array}$} & \multirow{2}{*}{$\begin{array}{c}\text { Straw dry weight } \\
\text { (g/ear) }\end{array}$} & \multirow{2}{*}{$\begin{array}{c}\text { Percentage of } \\
\text { disseminated } \\
\text { pollen } \\
\text { (average on } \\
\text { the } 3 \text { anthers } \\
\text { of a floret) }\end{array}$} & \multicolumn{2}{|c|}{ Frequency of anthers } & \multirow{2}{*}{$\begin{array}{c}\text { Rate of } \\
\text { out-crossing } \\
(\%)\end{array}$} \\
\hline & & & & & $\begin{array}{l}\text { With } 4 \\
\text { dehiscent } \\
\text { loculi } \\
(\%)\end{array}$ & $\begin{array}{c}\text { With } 4 \\
\text { dehiscent } \\
\text { loculi and still } \\
\text { containing } \\
\text { pollen grains } \\
(\%)\end{array}$ & \\
\hline Control & 41.4 & 0.37 & 1.6 & 82.9 & 86.1 & 14.3 & 10.2 \\
\hline Shaded & $\begin{array}{l}27.1 \\
* a\end{array}$ & $\begin{array}{l}0.33 \\
\mathrm{~ns}^{\mathrm{a}}\end{array}$ & $\begin{array}{l}2.1 \\
\mathrm{~ns}^{\mathrm{a}}\end{array}$ & $\begin{array}{l}57.6 \\
\star \mathrm{a}\end{array}$ & $\begin{array}{l}84.4 \\
\mathrm{~ns}^{\mathrm{b}}\end{array}$ & $\begin{array}{l}44.4 \\
\star \star b\end{array}$ & $\begin{array}{l}29.9 \\
* * b\end{array}$ \\
\hline
\end{tabular}


Table VIII. Effect of the developmental stage of the microsporocyte at the end of the treatment at low radiation on pollen viability at anthesis. Chamber experiment. Variety $\begin{gathered}\text { Combination of } \\ \text { temperature and radiation }\end{gathered}$
Microsporocyte developmental stage at the end of the $7 d$ treatment
Percentage of $F C R+$ pollen grains
Youngest florets of the ear

Microspore

Moulin

Moulin

Pernel

Pernel
$\operatorname{Tr}$

tr

$\operatorname{Tr}$

tr

\section{Oldest florets of the ear}

$\begin{array}{lr}\text { Microspore } & 8.8 \\ \text { Microspore } & 9.3 \\ \text { Microspore } & 78.2 \\ \text { Microspore } & 77.2\end{array}$

the FCR score correlates with the frequency of pollen germination and the rate of fertilization (Heslop-Harrison et al, 1984; Shivanna and Cresti, 1989; Shivanna et al, 1991), pollen functioning was presumably not affected by chilling temperatures. In the field experiment, temperatures below zero reduced grain set, but only slightly. These results differ from those of Kim et al (1985), who reported large reductions in pollen viability in barley when the temperature was below zero at meiosis. However they observed frost symptoms, whereas we did not; this could account for the difference in the responses of pollen viability. Single and Marcellos (1974) also reported that low temperatures between heading and anthesis only reduce grain set in wheat when there is frost.

Our results invalidate the interpretations of Couvreur and Masse (1985), Doussinault et al (1988) and Meynard and Sebillotte (1994), who assumed that the marked reduction in grain set was caused by low but positive temperatures close to meiosis. The plants used in their experiments were grown outdoors, and thus climatic parameters other than temperature presumably varied. The true cause of sterility was therefore difficult to identify.

Wheat thus responds to low temperatures at meiosis differently from many thermophilic crops, in which low positive temperatures induce pollen sterility (sorghum: Downes and Marshall, 1971; Brooking, 1976; rice: Satake and Hayase, 1974; Satake, 1991; coffee: Lanaud, 1983; mango: Issarakraisila and Considine, 1994).

\section{Effects of low radiation}

Tiller density of field grown crops is much higher than that of our chamber-grown plants.
Therefore, the incident photosynthetically active radiation per tiller in the chamber experiment was similar to the minima at meiosis in the field. In the field experiment, the incident radiation under the shades was low, but remained in the range that occurs in natural conditions. The shades were applied for a long period (12 d), so that all ears completed meiosis with low radiation.

Low radiation at meiosis reduced pollen viability in the chamber experiment. In the field experiment, the reduction in pollen dissemination in shaded plots shows that shading reduced pollination efficiency. The rate of hybrids in the progeny, which underestimates the rate of out-crossing, increased in response to shading. This confirmed that shading at meiosis caused the pollen of the variety Pernel to have a lower fertilizing capacity.

Our results confirm those of Fischer and Stockman (1980), showing that grain set is particularly susceptible to low radiation at meiosis, and they explain the cause of the reduction in kernel number. These authors observed that kernel number per ear was reduced more than chaff dry weight only if the plants were subjected to shading during a period which probably included meiosis. Similarly, in our experiment, kernel number per ear was more affected by low radiation than was chaff or straw dry weight. Thus, the close relationships between kernel number and chaff or straw dry weight (Boiffin et al, 1976, 1981; Fischer, 1985), which suggest that variations in these components result from the same factors, could be affected when grain set is reduced by limited pollen viability. This has also been suggested by Meynard and Sebillotte (1994).

The growth chamber treatments started when the first meiotic division occurred in the oldest florets of the main shoot. Most other florets were then still at pre-meiotic stages. All the treatments 
lasted $7 \mathrm{~d}$. The developmental stage at the end of the treatment was thus more advanced in plants kept at the control temperatures than in those that were chilled. All the florets at control temperature had completed meiosis, while some florets in chilled ears were still at pre-meiotic stages, or at the beginning of meiosis at the end of the experimental treatment (table VIII). Pollen viability at low radiation did not vary with the temperature. This suggests that the stage sensitive to low radiation was pre-meiosis, or the beginning of meiosis, as these stages were the only ones completed by all the florets.

\section{ACKNOWLEDGMENTS}

We thank S Ringuedé and L Le Rossignol for their technical assistance. We are grateful to JF Ledent for lending us the cold room used in the field experiment. A Edelman and O Parkes checked the English text.

\section{REFERENCES}

Alami S, Souvré A, Albertini L (1988) Effets de l'obscurité et du froid sur l'ontogenèse et la viabilité du pollen chez 2 variétés de sorgho-grain (Sorghum bicolor L Moench). Incidence sur les correspondances entre le développement végétatif, la taille des anthères et la formation du pollen. Rev Cytol Biol Végét-Bot 11, 13-41

Bennett MD, Finch RA, Smith JB, Rao MK (1973) The time and duration of female meiosis in wheat, rye and barley. Proc $R$ Soc London B 183, 301-319

Boiffin J, Sebillotte M, Couvreur F (1976) Incidence de la simplification du travail du sol sur l'élaboration des rendements du blé et du maïs. In: Simplification du travail du sol en production céréalière (ITCF, ed), tour Olivier-de-Serre, Paris, 240-280

Boiffin J, Caneill J, Meynard JM, Sebillotte M (1981) Élaboration du rendement et fertilisation azotée du blé d'hiver en Champagne crayeuse. I. Protocole et méthode d'étude d'un problème technique régional. agronomie 7, 549-558

Brooking IR (1976) Male sterility in Sorghum bicolor L Moench induced by low night temperature. I. Timing of the stage of sensitivity. Aust J Plant Physiol 3, 589-596

Couvreur F, Masse J (1985) Comportement comparé de quelques variétés selon les régions en 1984. $C R$ Acad Agri Fr 71, 887-893

Demotes-Mainard S (1994) Effets de rayonnements faibles et de températures basses à la méiose sur la fertilité gamétique du blé tendre d'hiver. Thèse de doctorat, INA PG, $178 \mathrm{p}$

Demotes-Mainard S, Doussinault G (1993) Effect of low irradiance before meiosis on the winter wheat response to low temperature and low radiation at meiosis. In: Crop Development for the Cool and Wet Regions of Europe. Crop Adaptation to Cool, Wet Climates (D Wilson, $\mathrm{H}$ Thomas, K Pithan, eds), Guyot, Brussels, 211-218

Doussinault G, Dosba F, Rousselle F, Douaire G (1988) Étude des déficiences de la fertilité de l'épi chez différentes lignées de blé tendre et leurs hybrides en liaison avec leur comportement méiotique. agronomie 8, 333-340

Downes RW, Marshall DR (1971) Low temperature induced male sterility in Sorghum bicolor. Aust $J$ Exp Agri \& Anim Husb 11, 352-356

Evans LT (1978) The influence of irradiance before and after anthesis on grain yield and its components in microcrops of wheat grown in a constant daylength and temperature regime. Field Crop Res 1, 5-19

Fischer RA (1985) Number of kernels in wheat crops and the influence of solar radiation and temperature. J Agric Sci Camb 105, 447-461

Fischer RA, Stockman YM (1980) Kernel number per spike in wheat (Triticum aestivum L) responses to preanthesis shading. Aust J Plant Physiol 7, 169180

Heslop-Harrison J, Heslop-Harrison $Y$ (1970) Evaluation of pollen viability by enzymatically induced fluorescence: intracellular hydrolysis in fluorescein diacetate. Stain Technol 45, 115-120

Heslop-Harrison J, Heslop-Harrison Y, Shivanna KR (1984) The evaluation of pollen quality, and a further appraisal of the fluorochromatic (FCR) test procedure. Theor App/ Genet 67, 367-375

Issarakraisila M, Considine JA (1994) Effects of temperature on pollen viability in Mango cV 'Kensington'. Ann Bot 73, 231-240

Kim SD, Park ME, Ha YW, Kwon YW (1985) Effect of low temperature on floral sterility, pollen viability and grain yield in barley and wheat. Res Rept RDA (Crops) 27, 114-119

Lanaud C (1983) Phénomènes de non-réduction provoqués par le froid au cours de la microsporogenèse du caféier. Café Cacao Thé 27, 259-274

Ledent JF, Detry JF, Leclerc G (1988) Effect of low temperatures around ear emergence on grain setting in wheat (Triticum aestivum L). In: Cereal Breeding Related to Integrated Cereal Production (ML Jorna, LAJ Slootmaker, eds), Pudoc, Wageningen, 74-77

Leterme P, Manichon H, Roger-Estrade J (1994) Analyse intégrée des rendements du blé tendre et de leurs causes de variation dans un réseau de parcelles d'agriculteurs du Thymerais. agronomie 14, 341-361

Meynard JM, Sebillotte M (1994) L'élaboration du rendement du blé, base pour l'étude des autres céréales à talles. In: Un point sur l'élaboration du rendement des principales cultures annuelles ( $\mathrm{L}$ Combe, D Picard, coordinateurs), INRA, Paris, 31. 51 
Saini HS, Aspinall D (1981) Effect of water deficit on sporogenesis in wheat (Triticum aestivum $\mathrm{L}$ ). Ann Bot 48, 623-633

Saini HS, Sedgley M, Aspinall D (1984) Developmental anatomy in wheat of male sterility induced by heat stress, water deficit or abscissic acid. Aust $J$ Plant Physiol 11, 243-253

Satake T (1991) Male sterility caused by cooling treatment at the young microspore stage in rice plants. XXX. Relation between fertilization and the number of engorged pollen grains among spikelets cooled at different pollen development stages. Jpn J Crop Sci $60,523-528$

Satake T, Hayase H (1974) Male sterility caused by cooling treatment at the young microspore stage in rice plants. X. A secondary sensitive stage at the beginning of meiosis. Proc Crop Sci Soc Jpn 43, 36-39

Shivanna KR, Cresti M (1989) Effects of high humidity and temperature stress on pollen membrane integri- ty and pollen vigour in Nicotiana tabacum. Sex Plant Reprod 2, 137-141

Shivanna KR, Linskens HF, Cresti M (1991) Pollen viability and pollen vigor. Theor Appl Genet 81, 3842

Single WV, Marcellos H (1974) Studies on frost injury to wheat. IV. Freezing of ears after emergence from the leaf sheath. Aust $J$ Agric Res 25, 679-686

Varlet-Grancher C, Moulia B, Sinoquet H, Russell G (1993) Spectral modification of light within plant canopies: how to quantify its effects on the architecture of the plant stand. In: Crop Structure and Light Microclimate. Characterization and Applications ( $\mathrm{C}$ Varlet-Grancher, R Bonhomme, H Sinoquet, eds), INRA, Paris, 427-451

Zhu CY (1989) Causes of high empty glume percentage in barley and control strategy. Zhejiang Agric Sci 5, 207-210 